PINHEIRO, JB; SILVA, GO; BISCAIA, D; MACEDO, AG; CORREIA, NM. 2019. Reaction of weeds, found in vegetable production areas, to root-knot nematodes Meloidogyne incognita and M. enterolobii. Horticultura Brasileira 37: 445-450. DOI - http://dx.doi.org/10.1590/S0102-053620190413

\title{
Reaction of weeds, found in vegetable production areas, to root-knot nematodes Meloidogyne incognita and M. enterolobii
}

\author{
Jadir B Pinheiro ${ }^{1 \mathbb{D}}$; Giovani Olegario da Silva ${ }^{2} \mathbb{D}$; Danielle Biscaia ${ }^{1} \mathbb{D}$; Amanda G Macedo ${ }^{3 \mathbb{D}}$; Núbia \\ Maria Correia $4 \mathbb{D}$
}

'Embrapa Hortaliças, Brasília-DF, Brasil; jadir.pinheiro@embrapa.br; danielle.biscaia@embrapa.br; ${ }^{2}$ Embrapa Hortaliças, EE de Canoinhas, Canoinhas-SC, Brasil; giovani.olegario@embrapa.br; ${ }^{3}$ Universidade de Brasília (UnB), Brasília-DF, Brasil; amandagomesma@gmail.com; [4Embrapa Cerrados, Brasília-DF, Brasil, nubia.correia@embrapa.br

\begin{abstract}
Root-knot nematodes cause great damage to vegetable crops in Brazil, besides having a large range of host plants, such as weeds. Weeds can maintain the inoculums or even favor the multiplication of these nematodes. In this study we evaluated the reaction of selected weed species, present in a vegetable production area, to root-knot nematodes Meloidogyne incognita and M. enterolobii. The trials were conducted in a greenhouse at Embrapa Hortaliças, Brasília-DF, in a completely randomized design with six replicates. Fifteen weed species were evaluated for $M$. incognita race 1 , and 16 weed species were evaluated for M. enterolobii. Two tomato cultivars were evaluated as resistance and susceptibility standards. Gall index (IG), egg mass index (IMO), number of eggs per gram of roots (eggs/g roots) and reproduction factor (FR) were evaluated. $M$. enterolobii survives and multiplies more easily in weeds collected in vegetable production areas than $M$. incognita race 1 and, the great majority of weed species evaluated in this study are hosts of both nematode species. Only the species Urena lobata, Sonchus oleraceus, Euphorbia heterophylla, Melampodium perfoliatum and Tagetes sp. were immune to $M$. incognita race 1. All evaluated species are either hosts or favor the multiplication of M. enterolobii. The species which are the most susceptible to $M$. incognita race 1 , and therefore require greater control of crops infected by this nematode are Ipomoea nil, I. triloba and Eleusine indica, and for M. enterolobii are I. nil, Solanum americanum, Hyptis suaveolens, Portulaca oleracea, I. triloba and Euphorbia heterophylla.
\end{abstract}

Keywords: Weed host, reproduction factor, dissemination.

\section{RESUMO}

Reação de plantas daninhas, presentes em áreas cultivadas com hortaliças, aos nematoides-das-galhas Meloidogyne incognita e M. enterolobii

Os nematoides-das-galhas causam muitos prejuízos às lavouras de hortaliças no Brasil, além de possuírem grande gama de plantas hospedeiras, incluindo as plantas daninhas. Estas podem manter o inóculo ou mesmo favorecer a multiplicação desses nematoides. Diante do exposto, objetivou-se com esse trabalho avaliar a reação de espécies selecionadas de plantas daninhas, presentes em áreas cultivadas com hortaliças, aos nematoides de galhas Meloidogyne. incognita e $M$. enterolobii. Os experimentos foram realizados em casa de vegetação na Embrapa Hortaliças, em Brasília-DF, em delineamento inteiramente casualizado, com seis repetições. Quinze espécies de plantas daninhas foram avaliadas para reação a $M$. incognita raça 1, e 16 espécies de plantas daninhas foram avaliadas para a reação a $M$. enterolobii. Duas cultivares de tomateiro foram utilizadas como padrão de resistência e suscetibilidade. As plantas daninhas foram avaliadas quanto ao índice de galhas (IG), índice de massas de ovos (IMO), número de ovos por grama de raízes (ovos/g raízes) e fator de reprodução (FR). M. enterolobii sobrevive e se multiplica com maior facilidade nas plantas daninhas coletadas em áreas cultivadas com hortaliças do que $M$. incognita raça $1 \mathrm{e}$, a maioria das espécies de plantas daninhas avaliadas são hospedeiras das duas espécies de nematoides. Apenas Urena lobata (malva-roxa), Sonchus oleraceus (serralha), Euphorbia heterophylla (amendoimbravo), Melampodium perfoliatum (estrelinha) e Tagetes sp. (cravode-defunto) foram imunes a $M$. incognita raça 1 . Todas as espécies avaliadas foram hospedeiras, ou propiciaram a multiplicação de $M$. enterolobii. As espécies mais suscetíveis ao M. incognita raça 1 e que, portanto, necessitam de maior controle nas lavouras infestadas por esse nematoide são Ipomoea nil (corda-de-viola), I. triloba (corda-de-viola) e Eleusine indica (capim-pé-de-galinha). Para $M$. enterolobii as espécies mais suscetíveis são I. nil (corda-deviola), Solanum americanum (maria-pretinha), Hyptis suaveolens (hortelã), Portulaca oleracea (beldroega), I. triloba (corda de viola) e Euphorbia heterophylla (amendoim-bravo).

Palavras chave: Hospedabilidade de plantas daninhas, fator de reprodução, disseminação. 
$\mathrm{T}$ he diversity of hosts and their interaction with other pathogens make the nematodes one of the main phytopathogens responsible for limiting agricultural productivity worldwide (Moens et al., 2009). These pathogens are widely distributed in the most diverse agricultural areas all over the world, in several annual and perennial crops, causing damages of approximately U\$ 157 billions annually (Bellé et al., 2017).

For vegetables, intensive cultivation has promoted the development of various diseases, such as occurrence of nematodes, with significant losses of heavily nematode-infested crops. Despite this pathogen's low natural mobility, constant soil tickler and machinery use, typical vegetable crop production operations, favor this spread. The root-knot nematode (Meloidogyne spp.) is quite destructive on most vegetables. In Brazil, M. javanica and $M$. arenaria are the most important pathogens on these crops (Pinheiro et al., 2018).

In Brazil, $M$. enterolobii sin. $M$. mayaguensis was reported parasitizing guava plants in the state of Bahia, causing several damages (Carneiro et al., 2001). This nematode has been identified in several plant species, including vegetables, in other regions of Brazil since then (Damaceno et al., 2016), even in cultivars resistant to other root-knot nematode species (Melo et al., 2011).

Weeds which grow next to crops can multiply the nematode inoculums and ensure the maintenance of high population densities of these pathogenic organisms in the soil, in the harvest or in the off season, making it difficult to control nematodes in production areas (Mônaco et al., 2009). Thus, characterizing weeds which are nematode hosts for suitable controlling in production areas is extremely important.

Studies on weed hosts to various species of root-knot nematodes can be found in literature, showing contrasting results, though. Moreover, no reports on evaluation of several weed species to $M$. enterolobii can be found. Given the above, the aim of this study was to evaluate the reaction of weeds, in vegetable production areas, to $M$. incognita and M. enterolobii.

\section{MATERIAL AND METHODS}

The trials were carried out in a greenhouse and the evaluations were done in the laboratory, at Embrapa Hortaliças, Brasília-DF, from October 23, 2014 to January 15, 2015.

The experimental design was completely randomized, with six replicates. Fifteen weed species were evaluated in relation to reaction to $M$. incognita race 1 , and 16 species were evaluated in relation to reaction to $M$. enterolobii. Weed seeds were obtained from Agrocosmos Company, located in Engenheiro Coelho-SP, and selected based on botanical survey on an area cultivated during several years with vegetables in Brasília.

The evaluated weeds in relation to two nematode species were Ipomoea nil (corda de viola), Solanum americanum (maria pretinha), Hyptis suaveolens (spearmint), Portulaca oleracea (purslane), I. triloba (corda de viola), Amaranthus hybridus (caruru roxo), Euphorbia heterophylla (amendoim bravo), Eleusine indica (capim pé de galinha), Bidens pilosa (picão preto), $A$. viridis (caruru de mancha), and, Tagetes sp. (marigold). Additionally, Urena lobata (malva roxa), Sida rhombifolia (guanxuma), Sonchus oleraceus (common sow thistle), Melampodium perfoliatum (estrelinha) for $M$. incognita race 1, and Sida cordifolia (guanxuma), Ageratum conyzoides (mentrasto), Acanthospermum australe (carrapichinho), Digitaria horizontalis (capim colchão) and Alternanthera tenella (apaga fogo) for M. enterolobii were also evaluated. Tomato 'Rutgers' was used as susceptibility standard, and tomato 'Nemadoro' as resistance standard to root-knot nematodes.

For both trials, female root-knot nematodes ( $M$. incognita), collected from tomato roots in the experimental area of Embrapa Hortaliças, and females of $M$. enterolobii obtained from guava crop in Petrolina-PE, were previously identified using isoenzyme standard
(Carneiro \& Almeida, 2001). Then, these pathogens were submitted to perineal cut and patterns described by Eisenback \& Hirschmann-Triantaphyllou (1991) for species identification. Nematodes were, then, multiplied on tomato plant 'Rutgers', kept in a greenhouse. $M$. incognita was identified using host test, according to Taylor \& Sasser (1978). After identification, nematodes were inoculated on tomatoes 'Rutgers', in order to produce and maintain the inoculums. About 45 days after inoculation, second stage eggs and juveniles (J2) were extracted from the plants to be used in the trials.

In both trials, weed specie's seeds were sown in $1.5-\mathrm{L}$ plastic pots containing substrate composed of soil, washed sand, cattle manure and rice husk, in 1:1:1:1 ratio. After 26 days, thinning was carried out, leaving one plant per pot (experimental plot). Then, the seeds were inoculated with suspension of 5,000 eggs and eventual second stage juveniles (J2) of the nematodes in $5 \mathrm{~mL}$ water distributed around the base of the plants.

At 56 days after inoculation, egg mass index (IMO) was evaluated. Root systems were washed in running water and stained during 15 minutes in an aqueous solution of phloxine B, $0.5 \mathrm{~g} / \mathrm{L}$ water (Taylor \& Sasser, 1978). Then, the number of eggs on the roots was counted, using a stereoscope microscope.

IMO and gall index (IG) were obtained according to Taylor \& Sasser (1978), using a note scale from 0 to 5. For IMO we considered: 0 ) roots without egg mass; 1) 1 to 2 egg masses; 2) from 3 to 10 egg masses; 3) from 11 to 30 egg masses; 4) from 31 to 100 egg masses and, 5) over 100 egg masses. Whereas for IG: 0) without galls; 1) 1 to 2 galls; 2) 3 to 10 galls; 3) 11 to 30 galls; 4) 31 to 100 galls and 5) over 100 galls.

To evaluate number of eggs per gram of roots (eggs/g roots), the roots were dried at room temperature during five hours, then weighed and processed according to Hussey \& Barker (1973) modified by Boneti \& Ferraz (1981).

Reproduction factor (FR) was obtained by the relationship between final and initial population densities 
$(\mathrm{FR}=\mathrm{Pf} / \mathrm{Pi})($ Oostenbrink, 1966). As initial population $(\mathrm{Pi})$, inoculums of 5,000 eggs and eventual juveniles (J2) were considered.

After verifying ANOVA assumptions, data were submitted to analysis of variance and Scott-Knott clustering test at 5\% probability, using GENES statistical software (Cruz, 2016).

\section{RESULTS AND DISCUSSION}

According to analysis of variance, significant differences $(p=0.05)$ were observed for all variables in relation to the reaction of weeds to nematodes. The genotypic and phenotypic coefficients of variation ratio, being superior to unit, show the predominance of genetic variation compared to environmental variation (Cruz et al., 2012). This fact shows reliability of estimates obtained for most evaluated traits. The authors observed exception for number of eggs per gram of roots (eggs/g roots) for $M$. enterolobii, showing that despite the detection of significant differences in weed reaction to this species, the results were unreliable.

Gall index (IG) and egg mass index (IMO) were similar for the evaluated weeds in relation to reaction to $M$. incognita race 1 , showing greater presence of galls and eggs in the susceptible control (tomato 'Rutgers'), followed by I. triloba and I. nil. Lower values for these indexes were obtained for Tagetes sp. and S. oleraceus, followed by the cluster formed by $S$. rhombifolia, $S$. americanum, $M$. perfoliatum, resistant control (tomato 'Nemadoro'), B. pilosa and $E$. heterophylla, and the cluster formed by $U$. lobata, $H$. suaveolens, $P$. oleracea, E. indica, A. hybridus and $A$. viridis (Table 1).

In relation to reproduction factor (FR) of $M$. incognita race 1 , in evaluated weeds and controls, the greatest value was obtained for the susceptible control 'Rutgers', showing the initial nematode population multiplied throughout vegetative cycle of the crop by a factor of 34.6 times. The second species in which greater nematode multiplication was noticed was I. triloba. Although not being statistically different from the most resistant species, $E$. indica and $I$. nil presented susceptibility reaction according to Oostenbrink (1966). Yet, according to this methodology used to evaluate the reaction of plants to Meloidogyne spp., S. rhombifolia, $S$. americanum, $H$. suaveolens, $P$. oleracea, A. hybridus, B. pilosa and $A$. viridis, they were considered resistant, it means, were hosts; but did not show final nematode population superior to the initial population, though. Urena Lobata, S. oleraceus, E. heterophylla, M. perfoliatum, Tagetes sp., and the resistant control, tomato cultivar Nemadoro, were immune, since they did not provide $M$. incognita multiplication

Table 1. Reaction of weed plants to Meloidogyne incognita race 1. Brasília, Embrapa Hortaliças, 2018.

\begin{tabular}{|c|c|c|c|c|c|}
\hline Family & Species & $I^{\prime} \mathbf{H}^{1}$ & IMO $^{1}$ & Eggs/g ${ }^{2}$ & $\mathbf{F R}^{3,4}$ \\
\hline \multirow[t]{2}{*}{ Amaranthaceae } & Amaranthus hybridus & $1.50 \mathrm{~d}$ & $1.67 \mathrm{~d}$ & $1441.76 \mathrm{c}$ & $0.84 \mathrm{c}(\mathrm{R})$ \\
\hline & Amaranthus viridis & $1.83 \mathrm{~d}$ & $1.33 \mathrm{~d}$ & $1954.70 \mathrm{c}$ & $0.50 \mathrm{c}(\mathrm{R})$ \\
\hline \multirow[t]{4}{*}{ Asteracea } & Bidens pilosa & $0.83 \mathrm{f}$ & $0.83 \mathrm{e}$ & $9.33 \mathrm{~d}$ & $0.02 \mathrm{c}(\mathrm{R})$ \\
\hline & Melampodium perfoliatum & $0.67 \mathrm{f}$ & $0.67 \mathrm{f}$ & $0.00 \mathrm{~d}$ & $0.00 \mathrm{c}(\mathrm{I})$ \\
\hline & Sonchus oleraceus & $0.17 \mathrm{~g}$ & $0.17 \mathrm{~g}$ & $0.00 \mathrm{~d}$ & $0.00 \mathrm{c}(\mathrm{I})$ \\
\hline & Tagetes sp. & $0.17 \mathrm{~g}$ & $0.17 \mathrm{~g}$ & $0.78 \mathrm{~d}$ & $0.00 \mathrm{c}(\mathrm{I})$ \\
\hline \multirow[t]{2}{*}{ Concolvulaceae } & Ipomoea nil & $3.00 \mathrm{c}$ & $3.17 \mathrm{c}$ & $3071.52 \mathrm{c}$ & $1.36 \mathrm{c}(\mathrm{S})$ \\
\hline & Ipomoea triloba & $3.83 \mathrm{~b}$ & $3.83 \mathrm{~b}$ & $7249.71 \mathrm{~b}$ & $12.63 \mathrm{~b}(\mathrm{~S})$ \\
\hline Euphorbiaceae & Euphorbia heterophylla & $0.83 \mathrm{f}$ & $0.83 \mathrm{e}$ & $33.33 \mathrm{~d}$ & $0.00 \mathrm{c}(\mathrm{I})$ \\
\hline Lamiaceae & Hyptis suaveolens & $1.17 \mathrm{e}$ & $1.00 \mathrm{e}^{\mathrm{e}}$ & $170.43 \mathrm{~d}$ & $0.12 \mathrm{c}(\mathrm{R})$ \\
\hline \multirow[t]{2}{*}{ Malvaceae } & Sida rhombifolia & $0.67 \mathrm{f}$ & $0.67 \mathrm{f}$ & $46.94 \mathrm{~d}$ & $0.09 \mathrm{c}(\mathrm{R})$ \\
\hline & Urena lobata & $1.00 \mathrm{e}$ & $1.00 \mathrm{e}$ & $0.00 \mathrm{~d}$ & $0.00 \mathrm{c}(\mathrm{I})$ \\
\hline Poaceae & Eleusine indica & $1.00 \mathrm{e}$ & $1.00 \mathrm{e}$ & $1187.56 \mathrm{c}$ & $2.63 \mathrm{c}(\mathrm{S})$ \\
\hline Portulacacea & Portulaca oleracea & $1.00 \mathrm{e}$ & $1.17 \mathrm{e}$ & $463.31 \mathrm{~d}$ & $0.15 \mathrm{c}(\mathrm{R})$ \\
\hline \multirow[t]{3}{*}{ Solanaceae } & Solanum americanum & $0.67 \mathrm{f}$ & $0.67 \mathrm{f}$ & $42.89 \mathrm{~d}$ & $0.01 \mathrm{c}(\mathrm{R})$ \\
\hline & Tomato Rutgers (susceptible) & $5.00 \mathrm{a}$ & $5.00 \mathrm{a}$ & $10480.45 \mathrm{a}$ & 34.62 a (S) \\
\hline & Tomato Nemadoro (resistant) & $0.67 \mathrm{f}$ & $0.67 \mathrm{f}$ & $0.00 \mathrm{~d}$ & $0.00 \mathrm{c}(\mathrm{I})$ \\
\hline General average & & 1.30 & 1.30 & 1378.36 & 2.79 \\
\hline $\mathrm{CVg} / \mathrm{CV}$ & & 2.58 & 2.69 & 1.58 & 2.69 \\
\hline
\end{tabular}

${ }^{1}$ Gall index (IG) and egg mass index (IMO) according to Taylor \& Sasser (1978); $0=$ roots without egg mass and/or galls; $1=$ roots with 1 to 2 egg masses and/or galls; $2=$ roots with 3 to 10 egg masses and/or galls; $3=$ roots with 11 to 30 egg masses and/or galls; $4=$ roots with 31 to 100 egg masses and/or galls; $5=$ roots with over 100 egg masses and/or galls; ${ }^{2}$ Eggs $/ g=$ number of eggs per gram of roots; ${ }^{3} \mathrm{FR}=$ reproduction factor (FR), final population/initial population; ${ }^{4}$ Resistance reaction according to Oostenbrink (1966): $\mathrm{I}=\mathrm{immune}(\mathrm{FR}=0)$; $\mathrm{R}=\mathrm{resistant}$ $(\mathrm{FR}<1)$ and $\mathrm{S}=$ susceptible $(\mathrm{FR}>1)$. Averages followed by same letters do not differ from each other, $\mathrm{Scott}-\mathrm{Knott}$ test $(\mathrm{p}<0.05)$. $\mathrm{CVg} / \mathrm{CV}=$ genotypic and phenotypic coefficients of variation ratio. 
(Table 1).

In general, we verified a relation between these species and their botanical family to $M$. incognita, except the Malvaceae, considering that the two evaluated species showed different responses: $U$. lobata was immune and $S$. rhombifolia, resistant. On the other hand, the two species of amaranths (Amaranthus hybridus and A. viridis) showed similar behavior: they both were resistant; three of the four species of Asteraceae were immune to the nematode (Melampodium perfoliatum, Sonchus oleraceus and Tagetes sp.); and the two species of Convolvulaceae (Ipomoea nil and I. triloba), were susceptible.

For reaction to $M$. enterolobii (Table 2 ), the greatest IGs were obtained for the two controls, tomatoes Rutgers (susceptible) and Nemadoro (resistant), and also $S$. americanum. The second cluster with the greatest IG was formed by I. nil, I. triloba and E. heterophylla. The lowest IGs were obtained in $A$. conyzoides, A. australe, $D$. horizontalis, E. indica, $A$. viridis and Tagetes sp. In relation to IMO, the species which showed greater values were $I$. nil and S. americanum, followed by the cluster formed by $H$. suaveolens, I. triloba and tomato 'Nemadoro', used as resistance standard. The species which showed the lowest IMO were $A$. conyzoides, $A$. australe, D. horizontalis, E. indica and Tagetes sp., followed by the cluster formed by $S$. cordifolia, A. hybridus, $A$. tenella and $A$. viridis.

The greatest number of $M$. enterolobii eggs per gram of roots was found in the susceptible control (tomato 'Rutgers') and in I. triloba, followed by the cluster formed by I. nil, S. americanum and $E$. heterophylla. The other species were clustered with lower number of eggs per gram of roots (Table 2). According to the clustering for FR, the highest value was obtained for tomato cultivar 'Rutgers', followed by $I$. nil, S. americanum, $I$. triloba, E. heterophylla, and tomato 'Nemadoro' (resistance standard); all of them were considered susceptible, according to Oostenbrink (1966). Using the same methodology, $H$. suaveolens and $P$. oleracea were also considered susceptible, although being clustered among species with lower FR. The other weed species were classified as resistant; any of them was considered immune to this nematode.

Considering the 11 common weed species in both trials, besides the two controls, we verified that $M$. enterolobii was more aggressive, managing to maintain or multiply on more weed species than $M$. incognita race 1 . Considering these weed species, eight were considered resistant or immune to M. incognita race 1, and only five were considered resistant or immune to $M$. enterolobii. Only E. indica showed to

Table 2. Reaction of weed plants to Meloidogyne enterolobii. Brasília, Embrapa Hortaliças, 2018.

\begin{tabular}{|c|c|c|c|c|c|}
\hline Family & Species & $I^{\prime} \mathbf{G}^{1}$ & IMO $^{1}$ & Eggs/g² & FR $^{3.4}$ \\
\hline \multirow[t]{2}{*}{ Amaranthaceae } & Alternanthera tenella & $1.00 \mathrm{e}$ & $1.00 \mathrm{e}$ & $43.00 \mathrm{c}$ & $0.02 \mathrm{c}(\mathrm{R})$ \\
\hline & Amaranthus hybridus & $1.00 \mathrm{e}$ & $1.00 \mathrm{e}$ & $3246.33 \mathrm{c}$ & $0.91 \mathrm{c}(\mathrm{R})$ \\
\hline Amaranthaceae & Amaranthus viridis & $0.50 \mathrm{f}$ & $0.50 \mathrm{e}$ & $105.17 \mathrm{c}$ & 0.11 c (R) \\
\hline \multirow[t]{4}{*}{ Asteracea } & Acanthospermum australe & $0.00 \mathrm{f}$ & $0.00 \mathrm{f}$ & $42.67 \mathrm{c}$ & $0.02 \mathrm{c}(\mathrm{R})$ \\
\hline & Ageratum conyzoides & $0.00 \mathrm{f}$ & $0.00 \mathrm{f}$ & $103.67 \mathrm{c}$ & $0.14 \mathrm{c}(\mathrm{R})$ \\
\hline & Bidens pilosa & $3.00 \mathrm{c}$ & $3.17 \mathrm{c}$ & $3477.50 \mathrm{c}$ & $0.91 \mathrm{c}(\mathrm{R})$ \\
\hline & Tagetes sp. & $0.00 \mathrm{f}$ & $0.00 \mathrm{f}$ & $7.67 \mathrm{c}$ & $0.04 \mathrm{c}(\mathrm{R})$ \\
\hline \multirow[t]{2}{*}{ Concolvulaceae } & Ipomoea nil & $4.00 \mathrm{~b}$ & $4.50 \mathrm{a}$ & $7966.83 \mathrm{~b}$ & $12.31 \mathrm{~b}(\mathrm{~S})$ \\
\hline & Ipomoea triloba & $4.17 \mathrm{~b}$ & $4.00 \mathrm{~b}$ & $16745.17 \mathrm{a}$ & $9.58 \mathrm{~b}(\mathrm{~S})$ \\
\hline Euphorbiaceae & Euphorbia heterophylla & $3.83 \mathrm{~b}$ & $3.50 \mathrm{c}$ & $8857.83 \mathrm{~b}$ & $12.45 \mathrm{~b}(\mathrm{~S})$ \\
\hline Lamiaceae & Hyptis suaveolens & $3.33 \mathrm{c}$ & $4.00 \mathrm{~b}$ & $2238.00 \mathrm{c}$ & 3.27 c (S) \\
\hline Malvaceae & Sida cordifolia & $0.83 \mathrm{e}$ & $0.83 \mathrm{e}$ & $297.33 \mathrm{c}$ & 0.03 c (R) \\
\hline \multirow[t]{2}{*}{ Poaceae } & Digitaria horizontalis & $0.00 \mathrm{f}$ & $0.00 \mathrm{f}$ & $10.50 \mathrm{c}$ & $0.02 \mathrm{c}(\mathrm{R})$ \\
\hline & Eleusine indica & $0.00 \mathrm{f}$ & $0.00 \mathrm{f}$ & $1.17 \mathrm{c}$ & $0.02 \mathrm{c}(\mathrm{R})$ \\
\hline Portulacacea & Portulaca oleracea & $2.00 \mathrm{~d}$ & $2.33 \mathrm{~d}$ & $1992.67 \mathrm{c}$ & $1.27 \mathrm{c}(\mathrm{S})$ \\
\hline \multirow[t]{3}{*}{ Solanaceae } & Solanum americanum & $5.00 \mathrm{a}$ & $5.00 \mathrm{a}$ & $10271.67 \mathrm{~b}$ & $15.33 \mathrm{~b}(\mathrm{~S})$ \\
\hline & Tomato Rutgers (susceptible) & $5.00 \mathrm{a}$ & $3.33 \mathrm{c}$ & $17752.00 \mathrm{a}$ & $27.15 \mathrm{a}(\mathrm{S})$ \\
\hline & Tomato Nemadoro (resistant) & $4.67 \mathrm{a}$ & $4.00 \mathrm{~b}$ & $4036.17 \mathrm{c}$ & $9.74 \mathrm{~b}(\mathrm{~S})$ \\
\hline General average & & 2.35 & 2.17 & 4559.90 & 5.53 \\
\hline $\mathrm{CVg} / \mathrm{CV}$ & & 3.73 & 2.98 & 0.70 & 1.48 \\
\hline
\end{tabular}

${ }^{1}$ Gall index (IG) and egg mass index (IMO) according to Taylor \& Sasser (1978); 0= roots without egg mass and/or galls; $1=$ roots with 1 to 2 egg masses and/or galls; $2=$ roots with 3 to 10 egg masses and/or galls; $3=$ roots with 11 to 30 egg masses and/or galls; $4=$ roots with 31 to 100 egg masses and/or galls; $5=$ roots with over 100 egg masses and/or galls; ${ }^{2} \mathrm{Eggs} / \mathrm{g}=$ number of eggs per gram of roots; ${ }^{3} \mathrm{FR}=$ reproduction factor (FR), final population/initial population; ${ }^{4}$ Resistance reaction according to Oostenbrink (1966): $\mathrm{I}=\mathrm{immune}(\mathrm{FR}=0)$; $\mathrm{R}=\mathrm{resistant}$ $(\mathrm{FR}<1)$ and $\mathrm{S}=$ susceptible $(\mathrm{FR}>1)$. Averages followed by same letters do not differ from each other, $\mathrm{Scott}-\mathrm{Knott}$ test $(\mathrm{p}<0.05) . \mathrm{CVg} / \mathrm{CV}=$ genotypic and phenotypic coefficients of variation ratio. 
be more resistant to $M$. incognita race 1 than to $M$. enterolobii. This higher virulence of $M$. enterolobii can also be confirmed by the average FR value, which was 5.53 for this nematode species and 2.79 for $M$. incognita race 1 .

The reaction of the weed species to M. enterolobii was directly related to botanical family. All tested Asteraceae species (Acanthospermum australe, Ageratum conyzoides, Bidens pilosa and Tagetes sp.) showed the same behavior: all they were resistant; the three amaranth species (Alternanthera tenella, Amaranthus hybridus and A. viridis) were also resistant; the two Convolvulaceae species were susceptible; and the two Poaceae species (Digitaria horizontalis and Eleusine indica) were resistant. These results show similar response of the weed species, belonging to the same family, to this nematode. This result is positive for further studies and nematode management strategies in the field. Weed differentiation at family or genus level is already sufficient to add information on nematode management, regardless of whether weed control is chemical, using herbicides; handpicking or mechanical, using a hoe, a harrow, a grid or growers.

Tomato 'Nemadoro', which presented immunity reaction to $M$. incognita race 1 , in relation to reproduction factor, with $E$. heterophylla and Tagetes sp, did not show the same immunity reaction to $M$. enterolobii. This result was expected for tomato, since this gene comprises resistance to $M$. incognita, M.javanica and $M$. arenaria, but does not show resistance to $M$. hapla and M. enterolobii. Meloidogyne enterolobii is known as a nematode which causes damages even to crops which carry genes showing resistance to other species of Meloidogyne spp. (Tigano et al., 2010).

Some studies about reaction of weeds to $M$. incognita can be found in literature. Mônaco et al. (2009) have studied the reaction of 57 species to $M$. incognita race 1 . Considering these species, E. heterophylla, A. hybridus, A. viridis, I. nil, S. rhombifolia, $S$. americanum and $S$. oleraceus were also evaluated in this study. Ipomea nil, S. oleraceus and S. americanum showed the same reaction in both studies. Euphorbia heterophylla was classified as resistant in the first study, A. hybridus and $A$. viridis, as susceptible; and $S$. rhombifolia, as immune; however, in this study, the first was considered immune and the others resistant.

Cordeiro et al. (2014) evaluated the reaction of 10 weed plants to $M$. incognita, without identifying the race, and among those which were common to this study, $E$. heterophylla, S. americanum, $B$. pilosa, all were considered resistant, which is in accordance with this study, considering the last two ones; whereas, $E$. heterophylla showed to be immune.

Thus, Bellé et al. (2017), studying the reaction of 34 weed plants to $M$. incognita, without identifying the race, verified that any species was immune to the nematode, 10 species were resistant and the others, susceptible. I. nil, E. indica, E. heterophylla, A. hybridus, A. viridis, B. pilosa, S. rhombifolia and $S$. americanum behaved the same way in this study. The first was considered susceptible, which is in accordance with this study; however, the others showed a different reaction. E. indica and $E$. heterophylla, which were classified as susceptible and resistant, respectively, in Bellé et al. (2017), were classified as resistant and immune, respectively, in this study; whereas all the other ones were considered susceptible in the cited study, and resistant in this study.

Similarly, Silva et al. (2013), evaluating the reaction of 23 weed species to $M$. incognita and M.javanica, without identifying races, concluded the same reaction pattern to two nematode species, considering 11 weed plants susceptible and 12 resistant. A. hybridus, $H$. suaveolens, $S$. americanum, B. pilosa and $E$. heterophylla were also evaluated in this study, and the reaction of B. pilosa was the same verified in this study; however, the others behaved differently: the three first ones were considered susceptible and in this study they were considered resistant. E. heterophylla was considered susceptible, in these evaluations it was considered immune. The same authors also evaluated $S$. cordifolia, another guanxuma species, which showed resistance standard, in accordance with this study for $S$. rhombifolia.

Contrasting reaction patterns of some weeds found in literature for $M$. incognita can be explained using different conditions of evaluations of the experiments, such as, inoculation time after sowing, inoculum density, origin of isolate, identification or not of the races, time of evaluation after inoculation, among other factors.

In relation to reaction of weed plants to M. enterolobii, Almeida et al. (2011) collected weed plants in areas infested by this nematode in guava plants (Psidium guajava), are common in this study $B$. pilosa and $S$. americanum. The results showed that both plants presented eggs and juveniles in their roots, as in this study. In a similar study, also collecting weed plants in an area under guava cultivation, infested by M. enterolobii, Carneiro et al. (2006) studying 10 species of weed plants and cultivated, among these weeds $B$. pilosa and Tagetes minuta, verified the presence of females of these nematodes in B. pilosa and absence of T. minuta, similar situation observed in this study. Souza et al. (2006), also using 14 weed plant species, among them $A$. hybridus and $S$. americanum, observed the presence of females of this nematode in the roots, confirming that this species of nematodes is polyphagous and that knowing the plants which host or multiply this nematode is important for the control.

In general, most weed species evaluated in this study were hosts for both nematodes. Only U. lobata, S. oleraceus, E. heterophylla, M. perfoliatum and Tagetes sp. were immune, it means, they neither hosted nor allowed the multiplication of $M$. incognita race 1 . However, all evaluated species were host or provided multiplication of $M$. enterolobii. The species which were the most susceptible to $M$. incognita race 1 , and that, therefore, need to be controlled more carefully in crops infected by this nematode were I. nil, I. triloba and $E$. indica. Regarding $M$. enterolobii were I. nil, S. americanum, $H$. suaveolens, $P$. oleracea, I. triloba and E. heterophylla. In addition, $M$. enterolobii species are more easily maintained and multiply in 
common weeds in vegetable crops than M. incognita race 1 .

\section{REFERENCES}

ALMEIDA, EJ; ALVES, GCS; SANTOS, JM; MARTINS, ABG. 2011. Assinalamentos de Meloidogyne enterolobii em goiabeira e em plantas invasoras no estado de São Paulo, Brasil. Nematologia Brasileira 35: 50-52.

BELLÉ, C; KULCZYNSKI, SM; KASPARY, TE; KUHN, PR. 2017. Plantas daninhas como hospedeiras alternativas para Meloidogyne incognita. Nematropica 47: 26-33.

BONETTI, JIS; FERRAZ, S. 1981. Modificações do método de Hussey \& Barker para extração de ovos de Meloidogyne exigua em raízes de cafeeiro. Fitopatologia Brasileira 6: 553.

CARNEIRO, RG; ALMEIDA, MRA. 2001. Técnica de eletroforese usada no estudo de enzimas dos nematoides de galhas para identificação de espécies. Nematologia Brasileira 25: 35-44.

CARNEIRO, RG; MOREIRA, WA; ALMEIDA, MRA; GOMES, ACMM. 2001. Primeiro registro de Meloidogyne mayaguensis em goiabeira no Brasil. Nematologia Brasileira 25: 223-228

CARNEIRO, RG; MÔNACO, APA; MORITZ, MP; NAKAMURA, KC; SCHERER, A. 2006. Identificação de Meloidogyne mayaguensis em goiabeira e em plantas invasoras, em solo argiloso, no Estado do Paraná. Nematologia Brasileira 30: 293-298.

CORDEIRO, CF; KOSMANN, CR; ESTEVEZ,
RL; ALEIXO, V; PETERS, FF. 2014. Reprodutividade e parasitismo de Meloidogyne incognita em plantas espontâneas do oeste paranaense. Scientia Agraria Paranaensis 13: 277-282.

CRUZ, CD; REGAZZI, AJ; CARNEIRO, PCS. 2012. Modelos biométricos aplicados ao melhoramento genético. $4^{\mathrm{a}}$.ed. Viçosa: Editora UFV. $514 \mathrm{p}$.

CRUZ, CD. 2016. Genes software-extended and integrated with the R, Matlab and Selegen. Acta Scientiarum Agronomy 38: 547-552.

DAMACENO, LS; QUEIROZ, MA; DIAS RDCS; CUNHA, JM; TEIXEIRA, FA. 2016. Avaliação de parentais e F1s em melancia quanto à reação ao Meloidogyne enterolobii. Caatinga 29: 296-304.

EISENBACK, JD; HIR SCHMANN TRIANTAPHYLLOU, H. 1991. Root-knot nematodes: Meloidogyne species and races. In: NICKLE, WR (ed). Manual of Agricultural Nematology. New York. p.191-274.

HUSSEY, RS; BARKER, KR. 1973. A comparison of methods of collecting inocula of Meloidogyne spp. Including a new technique. Plant Disease Reporter 57: 1025-1028.

MELO, OD; MALUF, WR; GONÇALVES, RJS; NETO, ACG; GOMES, LAA; CARVALHO, RC. 2011. Triagem de genótipos de hortaliças para resistência a Meloidogyne enterolobii. Pesquisa Agropecuária Brasileira 46: 829835.

MOENS, M; PERRY, RN; STARR, EJL. 2009. Meloidogyne species - a diverse group of novel and important species. In: Perry, RN; MOENS, M; STARR, JL (eds). Root-Knot Nematodes. Wallingford: CABI. p. 1-17.
MÔNACO, APA; CARNEIRO, RG; KRANZ, WM; GOMES, JC; SCHERER, A; SANTIAGO, DC. 2009. Reação de espécies de plantas daninhas a Meloidogyne incognita raças 1 e 3, a M. javanica e a M. paranaensis. Nematologia Brasileira 33: 235-242.

OOSTENBRINK, M. 1966. Major characteristics of the relation between nematodes and plants. Mededelingen Landbouw 4: 1-46.

PINHEIRO, JB; SILVA, GO; BISCAIA, D; MACÊDO, AG; RAGASSI, CF; SANTIAGO, DC. 2018. Reação de genótipos de batata ao nematoide-das-galhas Meloidogyne spp. em campos naturalmente infestados. Revista Latinoamericana de la Papa 22: 1-11.

SILVA, SL; SANTOS, TF; RIBEIRO, NR; SILVÉRIO, AT; MORAIS, TS. 2013. Reação de plantas daninhas a Meloidogyne incognita $\mathrm{e}$ M. javanica. Nematologia Brasileira 37: 3-4.

SOUZA, RM; NOGUEIRA, MS; LIMA, IM; MELARATO, M; DOLINSKI, C. 2006. Manejo do nematóide das galhas da goiabeira em São João da Barra (RJ) e relato de novos hospedeiros. Nematologia Brasileira 30: 165-169.

TAYLOR, A; SASSER, JN. 1978. Biology, identification and control of root-knot nematodes (Meloidogyne species). North Caroline: University Graphics. 111p.

TIGANO, M; SIQUEIRA, K; CASTAGNONESERENO, P; MULET, K; QUEIROZ, P; SANTOS, M; TEIXEIRA, C; ALMEIDA, M; SILVA, J; CARNEIRO, R. 2010. Genetic diversity of the root-knot nematode Meloidogyne enterolobii and development of a SCAR marker for this guava-damaging species. Plant Pathology 59: 1054-1061. 